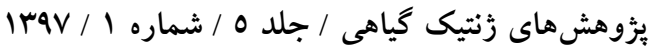

مقايسه تنوع DNA كلرويلاستى برخى زنوتيبهاى سيب ايرانى، ارقام تجارى و برخى پايههاى متداول

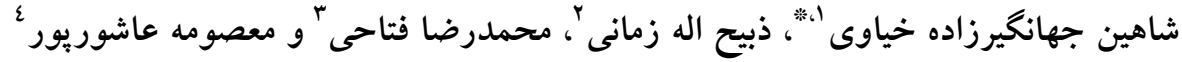
1- استاديار يزوهشى، يزوهشكده هاى، مؤسسه تحقيقات علوم باغبانى، سازمان تحقيقات، آموزش و ترويج كثاورزى،

$$
\begin{aligned}
& \text { لاهيجان } \\
& \text { r- استاد، گروه علوم باغبانى، دانشكده كثاورزى، دانشخاه تهران، كرج }
\end{aligned}
$$

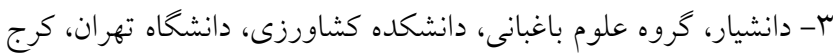

$$
\begin{aligned}
& \text { ع- كارشناس ارشد، سازمان جهاد كثاورزى گيلان، رشت }
\end{aligned}
$$

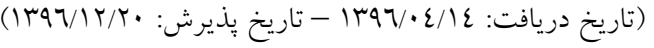

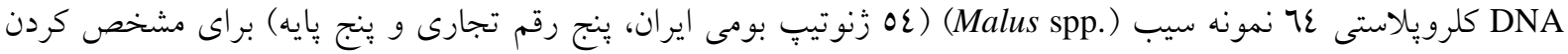
هايلوتايڤهاى آنها با كاربرد روش واكنش زنجيرهاى يلىمراز-تفاوت طول قطعات حاصل از هضم (PCR-RFLP) بررسى

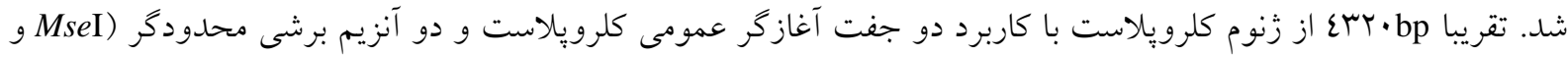
(EcoRI بررسى گرديد. تمام جهشهاى شناسايى شده، حذف-اضافه در محدوده bp •ع-• بودند. تركيب تمام جهشها،

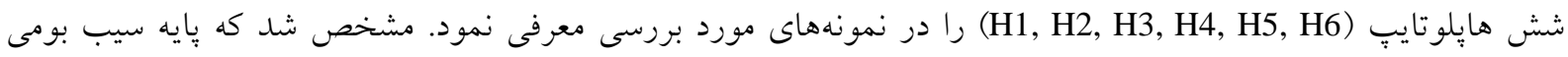

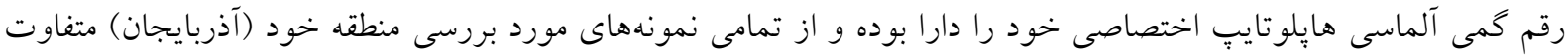

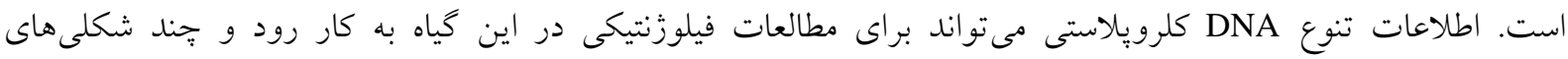
مشخص شده در زنوم سيتو يلاسمى با روش PCR-RFLP مىتواند به درى وراثت مادرى سيب كمك كند. وازگَان كليدى: آغازگر عمومى كلرويلاست، آنزيم برشى محدودگر، سيب، هايلوتايب، PCR-RFLP 
واكنش زنجيرهاى يلى مراز- تفاوت طول قطعات حاصل

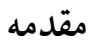

Polymerase Chain Reaction-Restriction ) هضم از Fragment Length Polymorphism, PCR-RFLP بررسى تنوع DNA كلرويّاستى بسيارى از گياهان استفاده Cros et al., 1998; Widmer and ) شده است Mohanty et al., 2001; Panda et Baltisberger, 1999; Kucuk et al., Salehi Shanjani, 2004; al., 2003; Coart et al., 2006; Turkec et al., 2006; 2006; Bouhadida et al., 2007; Jahangirzadeh Khiavi et al.,

جهانكيرزاده خياوى و همكاران ( Jahangirzadeh Khiavi (et al., 2013 ايران از منطقه آذربايجان و دو رقم تجارى و دو رقم پيايه باكوتاه كننده از روش CAPs با كاربرد ب جفت آغازگ عمومى كلروبِاست حدود براءع٪ از زنوم كلرويلاست را مورد يزّوهش قرار دادند. در بررسى آنها نمونهها در هشت هايلوتايبٍ قرار گرفتند كه تمام اين هايلو تايبٍها نتيجه جهش هاى حذف و اضافه بودند. توركج و همكاران (Turkec et al., 2006) با استفاده از نشانخرهاى cpSCAR ارقام گيلاس را مورد بررسى قرار دادند و مشاهده نمودند كه آناليز DNA كلرويلاست روش خوبى براى طبقه بندى ارقام گيلاس مى باشد و با

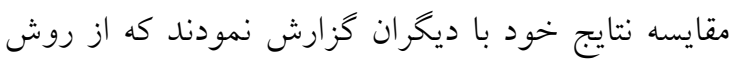
مى cpSCAR

براى بررسى ارتباط بين سيبهاى وحشى ارويايى و انواع اهلى شده و (Malus sylvestris (L.) Mill)

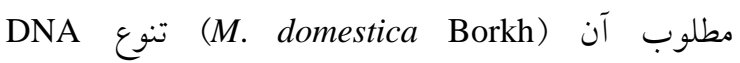
كلرويلاستى توسط دو روش SNP و PCR-RFLP مورد بررسى قرار گرفت كه با بررسى جند شكلىهاى تمام

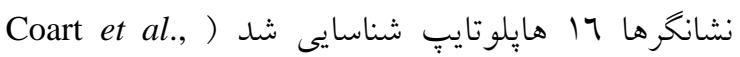

زين العابدينى و همكاران (Zeinalabedini et al., 2007) با بررسى تنوع زنتيكى 0 ع اكسيشن بادام توسط نشانكرهاى NDNA ،SSR هاى هستهاى بلى مورفيسم بيشترى نسبت به 


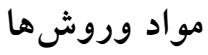

مواد گياهى: براى انجام اين تحقيق عا زنوتيبٍ و رقم

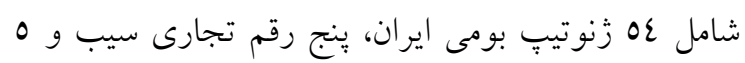

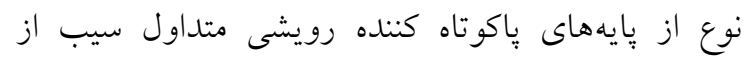

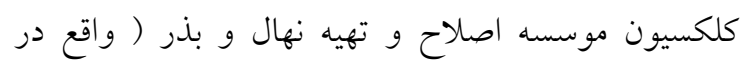

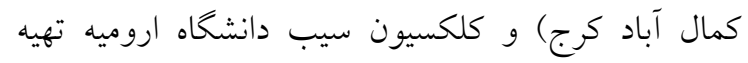
كرديد (جدول (1). برگهاى بالغ و كامل شده به به عنوان

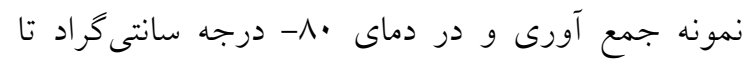

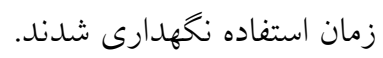

استخراج DNA :DNA زنومى از نمونههاى بركى جمع

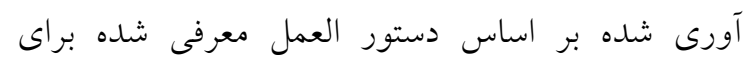

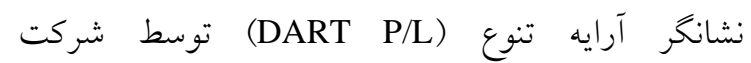
Diversity Arrays Technology Pty Ltd استخراج گرديد. (http://www.diversityarrays.com) تكثير قطعات DNA كلرويلاست: DNA كلرويلاست

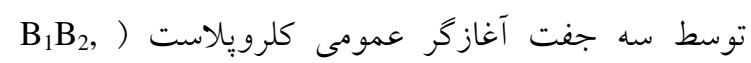
(Grivet et al., 2001) (K $\mathrm{K}_{1} \mathrm{~K}_{2}$, TF كرديد. مخلوط واكنش زنجيرهاى يلىمراز براى نمونهها

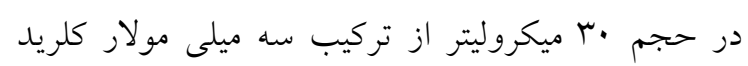

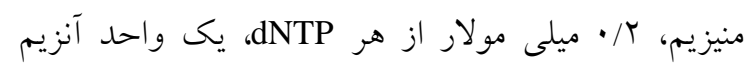

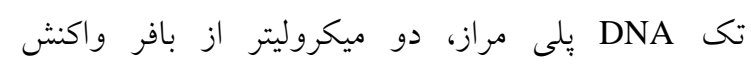

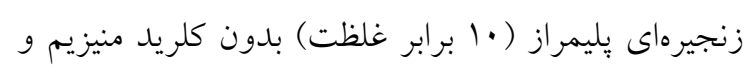

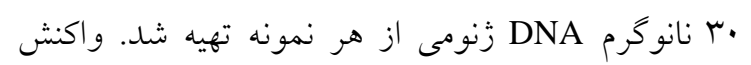

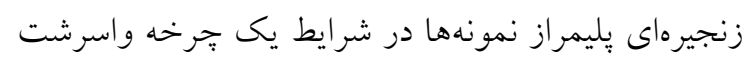

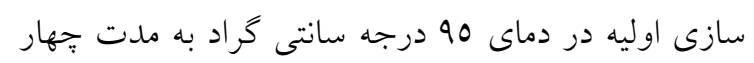

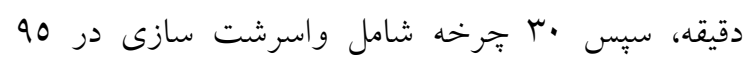

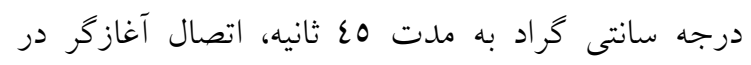

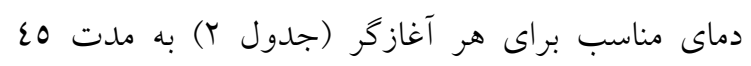

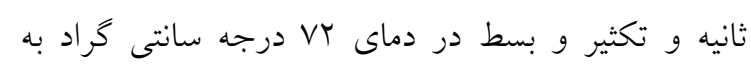

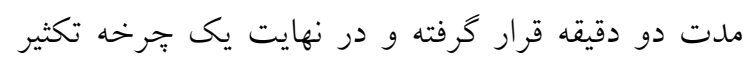

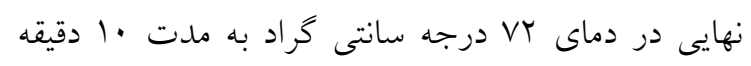

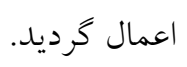

هاى كلرويلاستى نشان مىدهند و دليل اين امر را

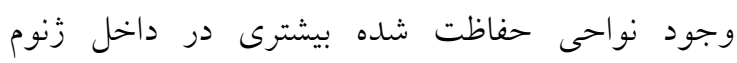
كلرويلاست بيان نمودند. ايشى كاوا و همكاران (Ishikawa et al., 1992) با استفاده از تفاوت هاى طول قطعات ناشى از هضم هن

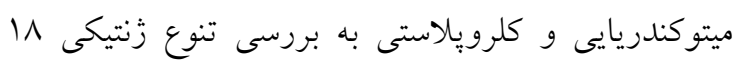

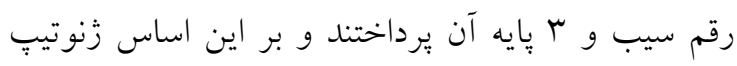

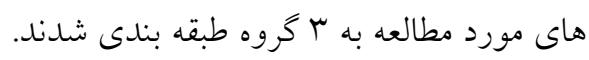

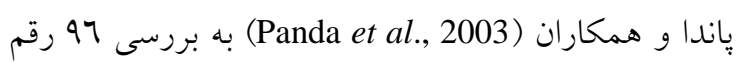
كيلاس (Prunus avium L.) و 0 رقم آلبالو (Prunus جهت مشخص كردن هايلوتيب هاى آنها رفي (cerasus 1.

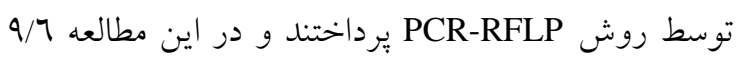

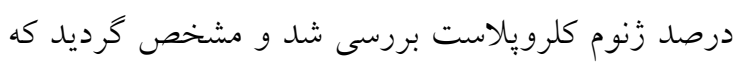

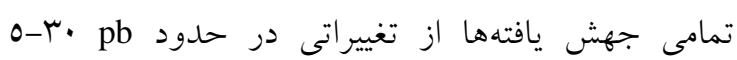

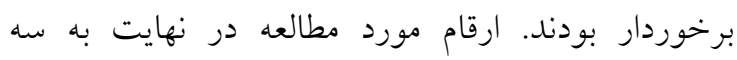

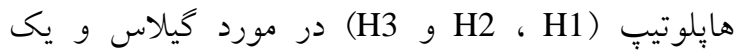
هايلوتيب (H4) در مورد آلبالو طبقه بندى شدند. نتايج اين

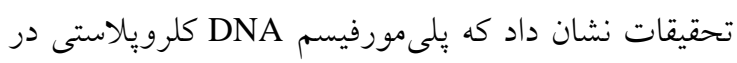
درى وراثت مادرى در كيلاس و آلبالو نقش موثرى ايفا

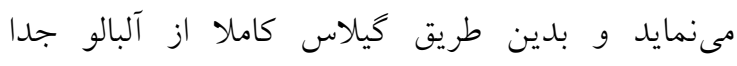
مى گردد. در اين مطالعه مشخص شد بد كه كيلاس والد مادرى آلبالو نمىباشد.

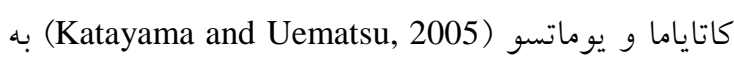

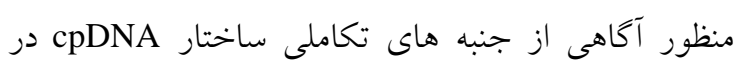

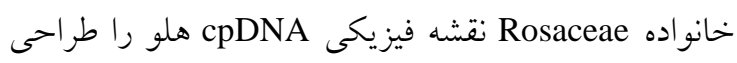

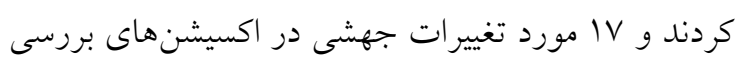

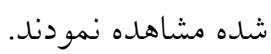

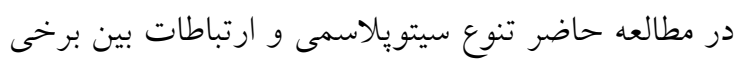
زنوتيبٍ هاى سيب بومى ايران، ارقام تجارى و برخى بايه

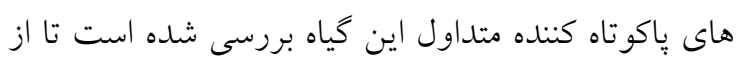

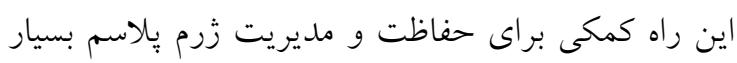
غنى سيب موجود در كشور ايران باشد. روند 


$$
\text { جدول ا- اسامى زنوتيٍّا، ارقام و پايههاى مورد بررسى، محل جمع آورى آنها و هايلوتايب شناسايى شده }
$$

Table 1. Name of studied genotypes, cultivars and rootstocks, their place of collection and determined haplotype

\begin{tabular}{|c|c|c|c|c|c|c|c|}
\hline رديف & $\begin{array}{c}\text { نام نمونه } \\
\text { Sample Name }\end{array}$ & $\begin{array}{l}\text { هايلوتايتٍ } \\
\text { Haplotype }\end{array}$ & $\begin{array}{c}\text { محل جمع آورى } \\
\text { Place of collection }\end{array}$ & $\begin{array}{l}\text { رديف } \\
\text { No }\end{array}$ & $\begin{array}{c}\text { نام نمونه } \\
\text { Sample Name }\end{array}$ & 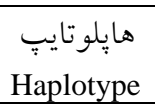 & $\begin{array}{c}\text { محل جمع آورى } \\
\text { Place of collection }\end{array}$ \\
\hline 1 & $\begin{array}{c}\text { Boomi meshkin } \\
\text { shahr }\end{array}$ & $\mathrm{H} 4$ & $\begin{array}{l}\text { Seed and plant } \\
\text { improvement } \\
\text { Institute }\end{array}$ & 33 & $\begin{array}{l}\text { Shafi Abadi } \\
\text { Chalous }\end{array}$ & H5 & $\begin{array}{l}\text { Seed and plant } \\
\text { improvement } \\
\text { Institute }\end{array}$ \\
\hline 2 & Azarbayjan 1 & $\mathrm{H} 3$ & 6 & 34 & Shahrood 10 & H6 & ' \\
\hline 3 & Azarbayjan 5 & $\mathrm{H} 4$ & ‘ & 35 & Shahrood 21 & H6 & ، \\
\hline 4 & Azarbayjan 6 & $\mathrm{H} 2$ & ‘ & 36 & Golab Nemati & $\mathrm{H} 3$ & ‘ \\
\hline 5 & Azarbayjan 7 & $\mathrm{H} 2$ & ' & 37 & $\begin{array}{c}\text { Golab } \\
\text { Damavand }\end{array}$ & $\mathrm{H} 1$ & ، \\
\hline 6 & Azarbayjan 8 & $\mathrm{H} 1$ & ، & 38 & Golab Paize & $\mathrm{H} 2$ & ‘ \\
\hline 7 & Azarbayjan 14 & $\mathrm{H} 4$ & ‘ & 39 & Torbati & H4 & ، \\
\hline 8 & ME 2 & $\mathrm{H} 2$ & ‘ & 40 & Ferdos & $\mathrm{H} 4$ & ، \\
\hline 9 & ME3 & H1 & ‘ & 41 & Aroos Mashhad & $\mathrm{H} 2$ & ' \\
\hline 10 & ME 4 & $\mathrm{H} 3$ & ‘ & 42 & Aroos Ghermez & H3 & ‘ \\
\hline 11 & ME 5 & $\mathrm{H} 2$ & ‘ & 43 & $\begin{array}{c}\text { Ghermez } \\
\text { Jangali }\end{array}$ & H1 & ' \\
\hline 12 & ME 6 & $\mathrm{H} 2$ & ‘ & 44 & Ghermez 1 & $\mathrm{H} 2$ & ‘ \\
\hline 13 & Ghermez Ahar & $\mathrm{H} 3$ & ‘ & 45 & Shemirani Khati & H6 & ‘ \\
\hline 14 & $\begin{array}{c}\text { Mahali Beyghi } \\
\text { Urmia }\end{array}$ & H1 & ' & 46 & $\begin{array}{c}\text { Shemirani } \\
\text { Dirras }\end{array}$ & $\mathrm{H} 3$ & ، \\
\hline 15 & Ghara Yarbagh & $\mathrm{H} 2$ & c & 47 & $\begin{array}{l}\text { Shemirani } \\
\text { Tabestane }\end{array}$ & H6 & ‘ \\
\hline 16 & Khan Almasi & $\mathrm{H} 2$ & ' & 48 & $\begin{array}{c}\text { Tabestane } \\
\text { Zodras Oghlid }\end{array}$ & $\mathrm{H} 3$ & ، \\
\hline 17 & Shahe Kord 8 & $\mathrm{H} 4$ & ‘ & 49 & $\begin{array}{c}\text { Tarhe Golabi } \\
\text { Arak }\end{array}$ & H6 & ، \\
\hline 18 & T3 & $\mathrm{H} 2$ & ‘ & 50 & SBA & $\mathrm{H} 3$ & ‘ \\
\hline 19 & $\mathrm{~T} 4$ & $\mathrm{H} 2$ & ‘ & 51 & $\mathrm{HGH}$ & H6 & ‘ \\
\hline 20 & $\begin{array}{l}\text { Boshghabi } \\
\text { Taleghan }\end{array}$ & $\mathrm{H} 2$ & c & 52 & Golden Asiai & H6 & ، \\
\hline 21 & Malayer 1 & $\mathrm{H} 2$ & ‘ & 53 & Golden Asiai 1 & $\mathrm{H} 4$ & ‘ \\
\hline 22 & Malayer 3 & $\mathrm{H} 1$ & ، & 54 & $\begin{array}{l}\text { Golden } \\
\text { Delicious }\end{array}$ & $\mathrm{H} 1$ & ، \\
\hline 23 & Malayer 5 & $\mathrm{H} 2$ & ‘ & 55 & Red Delicious & $\mathrm{H} 4$ & ‘ \\
\hline 24 & Malayer 8 & $\mathrm{H} 2$ & ‘ & 56 & Gala & H5 & ‘ \\
\hline 25 & Malayer & H1 & ‘ & 57 & Fuji & H5 & ‘ \\
\hline 26 & Palestini & H3 & ' & 58 & Granny Smith & H5 & ، \\
\hline 27 & Torsh Mesri & $\mathrm{H} 4$ & ‘ & 59 & Gami Almasi & H6 & ، \\
\hline 28 & Torsh Damavand & H5 & ‘ & 60 & M7 & $\mathrm{H} 3$ & ‘ \\
\hline 29 & $\begin{array}{c}\text { Torsh } \\
\text { Kermanshah }\end{array}$ & H5 & ' & 61 & M9 & H6 & ‘ \\
\hline 30 & Torsh Chalous & H5 & ‘ & 62 & M26 & H5 & ، \\
\hline 31 & Torshak Chalous & H5 & ' & 63 & M4 & $\mathrm{H} 3$ & ' \\
\hline 32 & Torsh Meigon & $\mathrm{H} 5$ & ' & 64 & MM109 & $\mathrm{H} 4$ & ' \\
\hline
\end{tabular}

جدول r- شرايط واكنش زنجيره اى بليمراز، تو الى آغاز گرها، اندازه قطعات تكثير شده و كيفيت تكثير

Table 2. PCR conditions, primers sequence, size of amplified fragment and quality of amplification

\begin{tabular}{|c|c|c|c|c|}
\hline $\begin{array}{c}\text { نام آغازگر } \\
\text { Primer name }\end{array}$ & $\begin{array}{c}\text { تو الى آغازگر } \\
\text { Sequence } \\
\text { 5'-3' }\end{array}$ & $\begin{array}{c}\text { دماى اتصاز کرهال } \\
\text { Annealing } \\
\text { temperature } \\
\left.\text { ( }{ }^{\circ} \mathrm{c}\right)\end{array}$ & $\begin{array}{l}\text { طول قطعه تكثير شده } \\
\text { Size of amplified } \\
\text { fragment } \\
\text { (bp) }\end{array}$ & $\begin{array}{c}\text { درجه تكثير } \\
\text { Degree of } \\
\text { amplification }\end{array}$ \\
\hline B1B2 & $\begin{array}{l}\text { F: TGCCTTGGTATCGTGTTCATAC } \\
\text { R: CYTGTCTTYTTGTAGTTGGAT }\end{array}$ & 55 & 1740 & ++ \\
\hline K1K2 & $\begin{array}{c}\text { F: GGGTTGCCCGGGACTCGAAC } \\
\text { R:CAACGGTAGAGTACTCGGCTTTTA }\end{array}$ & 54.5 & 2580 & ++ \\
\hline $\mathrm{TF}$ & $\begin{array}{l}\text { F: CATTACAAATGCGATGCTCT } \\
\text { R: ATTTGAACTGGTGACACGAG }\end{array}$ & 57.5 & - & NA \\
\hline
\end{tabular}

* No Amplification; ++ Perfect Amplification 
در رابطه با اندازه قطعه تكثير شده توسط يرايمر K1K2 Jahangirzadeh ） نيز جهانگيرزاده خياوى و همكاران نتايج مشابهى را گزار ش نمودداند. (Khiavi et al., 2013 از جهار تركيب آغازگر - آنزيم برشى بكار برده شده،

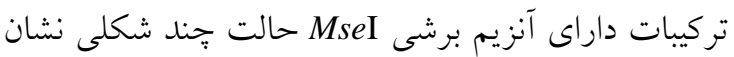
ندادند (تركيب B1B2- MseI داراى جايگاه برش نبود ولى تركيب K1K2-MseI قطعات يكسانى توليد نمود).

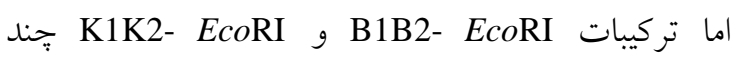
B1B2- شكلىهاى مناسب را ايجاد نمودند كه تركيب EcoRI حالت جند شكلى و تركيب K1K2- EcoRI به علت رخ داد يك جهش حذف/اضافه توليد دو حالت جند شكلى نمودند كه دامنه اين جهشها bp •ع-·• بود (جدول س). جهانگيرزاده خياوى و همكاران ( Jahangirzadeh Khiavi (et al., 2013 نظر جايكاه برش، حالات جندشكلى و يك شكلى، و و اندازه قطعات براى سيبهاى بومى منطقه آذربايجان و ارقام و پِيههاى ياكوتاه كننده گزارش نمودهاند.

جهشهاى حذف و اضافه در تركيبات B1B2- EcoRI و در شكل 1 و ح حالات يك شكلى تركيبات M1K2-MseI و در شكل Y براى تعدادى از نمونهها نشان داده شده است. تركيب تمام حالات جهش هاى شناسايى شده با يكديخر توليد شش هايلوتايبٍ متفاوت نمود (جدول ع). شناسايى هايلوتايبّها به اين صورت انجام گرفت كه به قطعه بزرگتر حاصل از برش

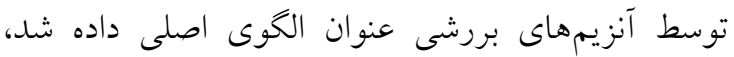
حرف اول كدها از برايمر، حرف دوم نام آنزيم برشى و حرف سوم كه بصورت انديس امده است به قطعه حاصل

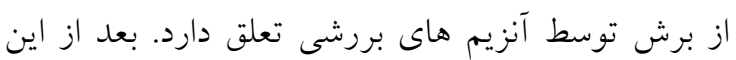
كد كذارى نمونههايى كه با يكديخر داراى كدهاى مشابه بريه بودند در يك هايلوتايتٍ قرار گرفتند. از آنجايى كه تمام قطعات تكثير شده در واكنش PCR يكنواخت و هم اندازه بودند لذا با بررسى تنها يك قطعه حاصل در تركيب B1B2- EcoRI يا دو حالت تركيب K1K2- EcoRI مىتوان تمام حالتهاى هايلو تاييى را مشخص نمود.
براى آكاهى از نتيجه تكثير DNA حجم ينج ميكروليتر از محلول واكنش زنجيرهاى يليمراز، سه ميكروليتر بافر

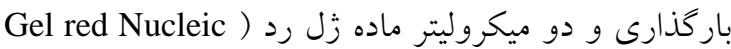
در زل ( acid, Biotium, cat: 41003-3-1-10ml به مدت دوساعت و نيم در •V ولت الكتروفورز و عكسبردارى زير نور ماورا بنفش صورت يذيرفت از

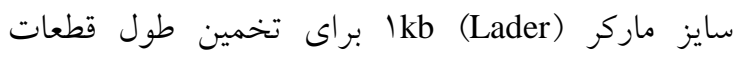
حاصل از تكثير استفاده خرديد. هضم و برش توسط آنزيم برشى: هضم و برش قطعات تكثير شده در واكنش زنجيرهاى يليمراز توسط دو آنزيم

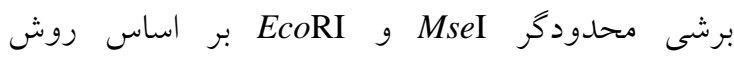
يبشنهادى شركت توليد كننده (Fermentas, Germany) صورت گرفت به اين صورت كه مخلوط برش حاوى ينج

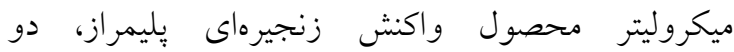
ميكروليتر بافر هضم ( •ا برابر غلظت)، •ا واحد آنزيم 1. برشى در حجم نهايى اس ميكروليتر بود وبه مدت ساعت در دماى V M درجه سانتى گراد براى EcoRI و 70 درجه سانتى گراد براى MseI انجام يذيرفت (براى تنظيم

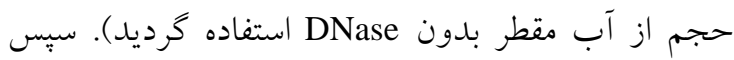

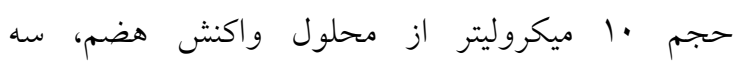
ميكروليتر بافر بارگذارى و دو ميكروليتر ماده زل رد در

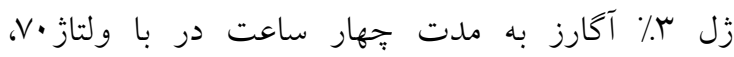

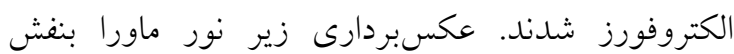

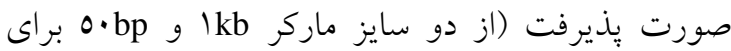
تخمين طول قطعات حاصل از هضم استفاده گرديد). نتايج و بحث

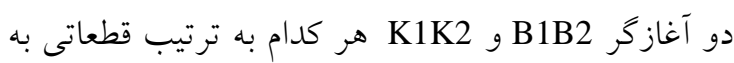

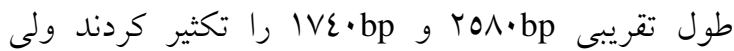
آغازگر TF تكثيرى انجام نداد. جهانگيرزاده خياوى و همكاران (Jahangirzadeh Khiavi et al., 2013) نيز در ارتباط با آغازگر TF در بررسى روى سيبهاى بومى

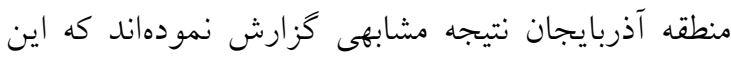
عدم تكثير در نمونهها مىتواند به دليلى رخ دادن جهش

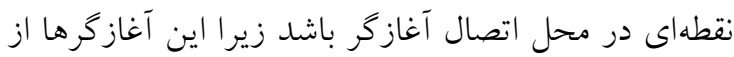
روى گياه تنباكو (Grivet et al., 2001) طراحى شدهاند. 


$$
\text { جدول ب- الخوى اصلى و متغير (bp) در جايخاه هاى جند شكلى به دست آمده توسط تركيب آغاز خر - آنزيم برشى }
$$

Table 3. Major patterns and variants (bp) of fragments revealed in each polymorphic site detected with different primer pair-restriction enzyme combinations

\begin{tabular}{ccc}
\multicolumn{1}{c}{ Length of mutation } \\
\cline { 2 - 3 } Polymorphic Site
\end{tabular}

$$
\text { جدول ع- فر اوانى هايلو تايبٍ هاى شناسايى شده }
$$

\begin{tabular}{|c|c|c|}
\hline هايلوتايبِها & تعلداد & فر اوانى \\
\hline Haplotypes & Number & Frequency \\
\hline$\left(\mathrm{BE}_{\mathrm{a}} \mathrm{KE}_{\mathrm{a}}\right) \mathrm{H} 1$ & 8 & 0.125 \\
\hline$\left(\mathrm{BE}_{\mathrm{a}} \mathrm{KE}_{\mathrm{b}}\right) \mathrm{H} 2$ & 16 & 0.250 \\
\hline$\left(\mathrm{BE}_{\mathrm{b}} \mathrm{KE}_{\mathrm{a}}\right) \mathrm{H} 3$ & 11 & 0.172 \\
\hline$\left(\mathrm{BE}_{\mathrm{b}} \mathrm{KE}_{\mathrm{b}}\right) \mathrm{H} 4$ & 10 & 0.156 \\
\hline$\left(\mathrm{BE}_{\mathrm{c}} \mathrm{KE}_{\mathrm{a}}\right) \mathrm{H} 5$ & 10 & 0.156 \\
\hline$\left(\mathrm{BE}_{\mathrm{c}} \mathrm{KE}_{\mathrm{b}}\right) \mathrm{H} 6$ & 9 & 0.141 \\
\hline Total & 64 & 1.000 \\
\hline
\end{tabular}

Table 4. Frequency of determined haplotype

a)

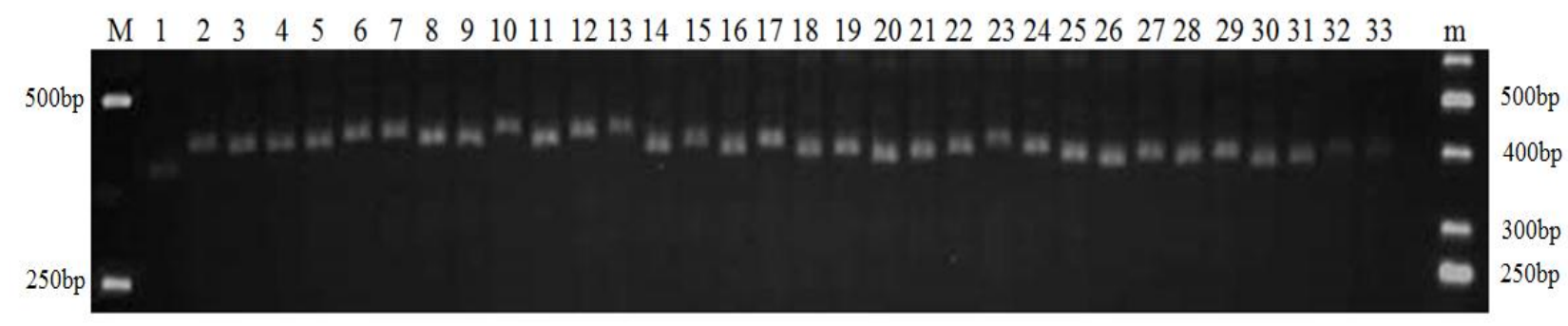

b)

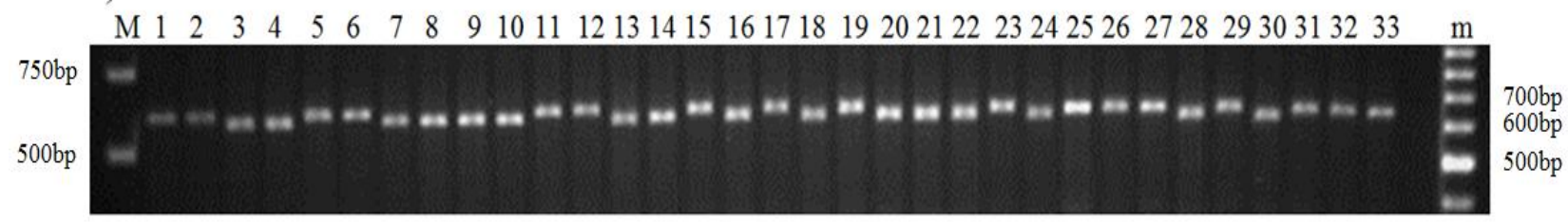

Kن

Figure 1. Restriction patterns in combinations of $\mathrm{B}_{1} \mathrm{~B}_{2}-E c o \mathrm{RI}$ (a) and $\mathrm{K}_{1} \mathrm{~K}_{2}-E c o \mathrm{RI}$ (b) 


\section{a)}

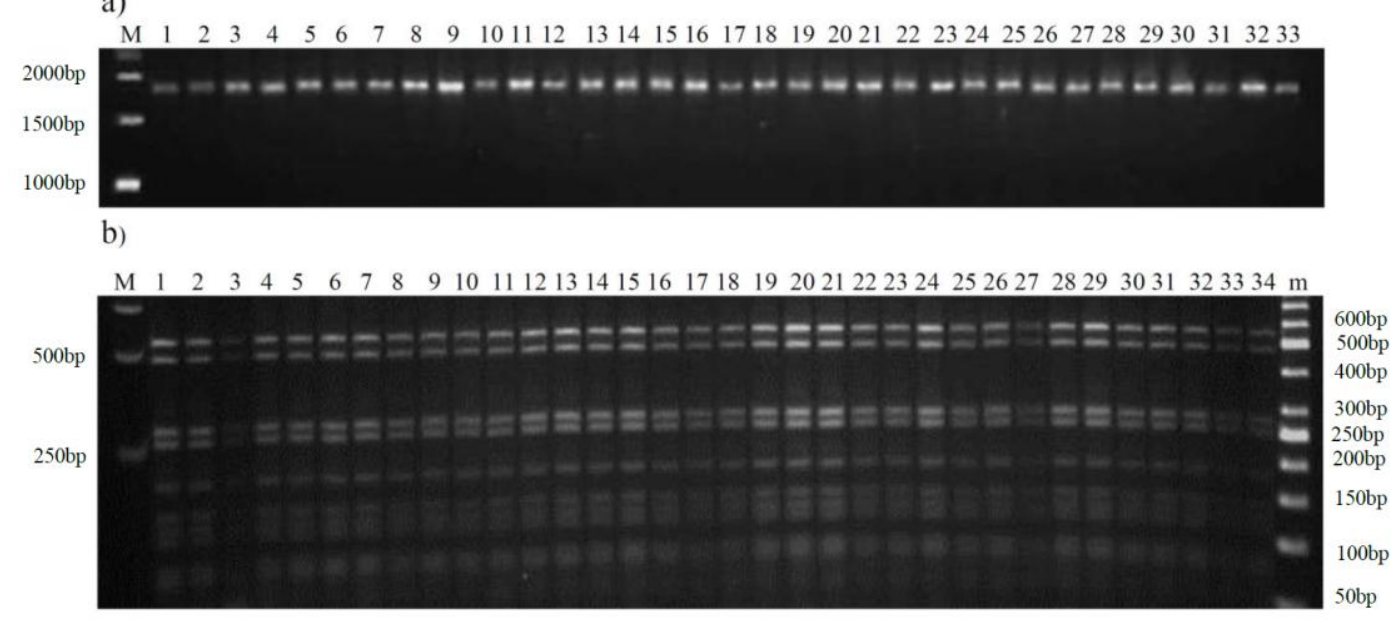

شكل r - الكوهاى برش تركيبات

Figure 2. Restriction patterns in combinations of $\mathrm{B}_{1} \mathrm{~B}_{2}-$ Mse I (a) and $\mathrm{K}_{1} \mathrm{~K}_{2}-$ MseI (b)

فراوانى (1/0\%) فقط شامل گمى آلماسى (بايه باكوتاه

$$
\text { كننده بومى ايران) مى باشند. }
$$

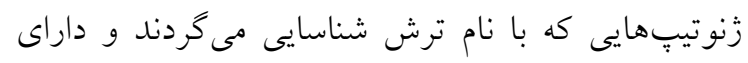
كستردگى زيادى در سطح كشور ايران هستند در يكى هايلوتايبٍ (H5) قرار كرفتند (ترش مصرى از منطقه شمال غرب به صورت استثنا در هايلوتايبٍ ديخرى (H4) قرار گرفته است). در بررسى جهانخيرزاده خياوى و همكاران (Jahangirzadeh Khiavi et al., 2013) نيز نمونهاى ترش منطقه البرز مركزى (ترش دماوند و ترش جالوس؛ نمونههاى با كد ب و و •r در بررسى حاضر) در

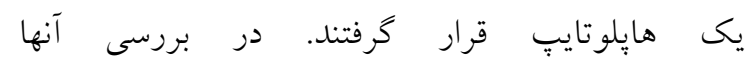
نيز ترش مصرى (Jahangirzadeh Khiavi et al., 2013) از باقى نمونهها مجزا قرار كرفت. از اين نتيجه نكتهاى كه محتمل است داشتن جد مادرى يكسان براى اين زَنوتيِها مىباشد. اما براى بيان مطلق اين نكته نياز به ميه

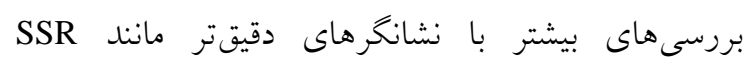
احساس مى گردد. يايههاى مالينخ و مالينخ مرتون مورد

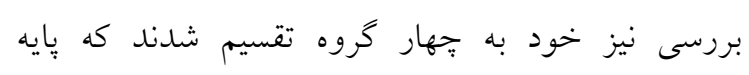

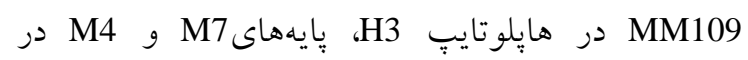

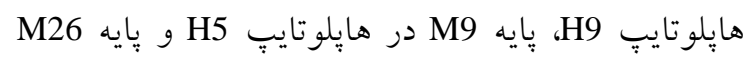
در هايلوتايتٍ H6 قرار كرفتند كه جدا شدن M9 و M26 از يكديخر با نتايج اعلام شده توسط ايشيكاوا و همكاران همخوانى دارد. در اين بررسى (Ishikawa et al., 1992)
در بررسى جهانخيرزاده حياوى و همكاران نيز به اين نحوه (Jahangirzadeh Khiavi et al., 2013) عمل شده است. DNA كلرويلاستى بطور كلى به علت حفاظت شدگى بالايى كه دارد ( Curtis and Clegg.

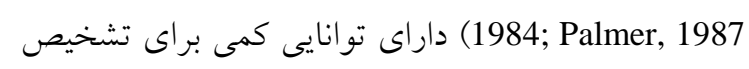
تفاوتهاى درون كونهاى مىباشد. DNA كلرويلاستى

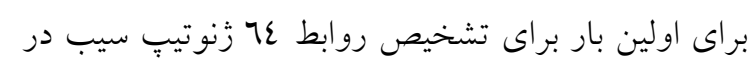

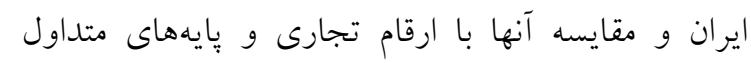
ياكوتاه كننده توسط روش PCR-RFLP مورد آزمون قرار

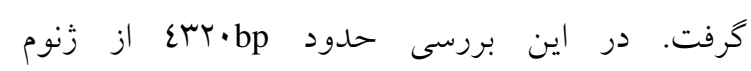

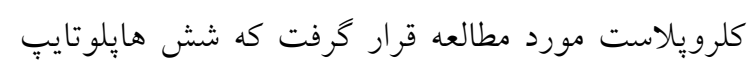

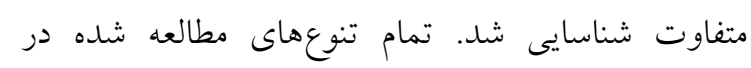

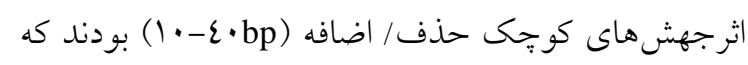

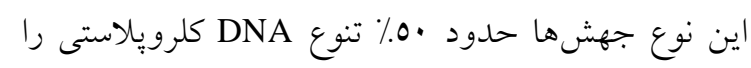
سبب مى كردند (Gielly and Taberlet, 1994). جهانگيرزاده خياوى و همكاران ( Jahangirzadeh Khiavi (et al., 2013 سيبهاى بومى منطقه آذربايجان را در همين محدوده كزارش نمودماند. (Y.0.bp) با توجه به اطلاعات حاصل مشخص كرديد كه رنه زنوتيِهاى ناحيه شمال غرب ايران خود به ينج كروه

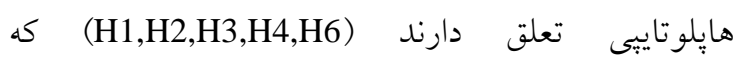
هايلوتايتٍ H4 با حداكثر فراوانى (11/) و H6 با حداقل 
يكديخر نزديك بودند، نيز در يك حالت هايلوتاييى (H4) قرار كرفتند كه اين حالت نشان از آن مىباشد كه اين دو نمونه احتمالا داراى جد مادرى اوليه يكسان اند. تعداد زياد هايلوتايبٍ هايى كه در دو منطقه البرز مركزى و دامنه زاكرس ديده شد با نتايج حاصل از مطالعات كاتو و همكاران (Kato et al. 1993) كه در عا زنوتيب سيب لي هايلوتايبٍ را شناسايى نمود، هماهنكى نشان مىدهد و به اين دليل به تعداد بالاى هايلوتايبٍهاى اين دو منطقه نمى توان با ديده ترديد نخريست. به طور كلى، نتايج حاصل از اين بررسى نشان مىدهد كه مطالعه كوناگونى DNA كلرويلاستى با تكستن جامعههاى بزرگ به جمعيتهاى كوجّى و مهيا كردن شرايط براى بررسى نمونهها توسط نشانخرهاى دقيقتر مانند ريزماهوارهها در حجم كارى كمتر بسيار مناسب مىباشد. بطورى كه فقط كافى است كه نمونههاى داخل يك گروه هايلوتايبى با يكديخر مقايسه و بررسى شوند. در اين ارتباط روش PCR-RFLP براى مشخص نمودن تفاوتهاى هايلوتاييى بين نمونهها يك روش بسيار

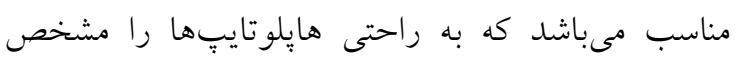
مىنمايد. البته براى افزايش دقت تعيين هايلوتايتٍا كاربرد آنزيمهاى برشى بيشتر يا تكثير قطعات متفاوت و بررسى آنها نيز تاثير زيادى دارند كه بايد مدنظر قرار كيرد.

\section{References}

Bagheri, A., Kochaki, A. and Zand, A. (1996). Plant Breeding in Sustainable Agriculture. Mashhad University Jihad publications. Mashhad, IR (In Persian).

Bouhadida, M., Martín. J.P., Eremin, G., Pinochet, J., Moreno, M.Á. and Gogorcena, Y. (2007). Chloroplast DNA diversity in Prunus and its implication on genetic relationships. Journal of the American Society for Horticultural Science, 132(5): 670-679.

Coart, E., Van Glabeke, S., De loose, M., Larsen, A.S. and Roldan-ruiz, I. (2006). Chloroplast diversity in the genus Malus: New insights into the relationship between the European wild apples (Malus sylvestris (L.) Mill.) and the domesticated apple (Malus domesticaBorkh.). Molecular Ecology, 15: 2171-2182.

Cros, J., Combes, M.C., Trouslot, P., Anthony, F., Hamon, S., Charrier, A. and Lashermes, P. (1998). Phylogenetic analysis of chloroplast DNA variation in CoffeaL. Molecular Phylogenetics and Evolution, 9(1): 109-117.

Curtis, S.E. and Clegg, M.T. (1984). Molecular evolution of chloroplast DNA sequences. Molecular Biology and Evolution, 1: 291-301.

Demesure, B., Sodzi, N. and Petit, R.J. (1995). A set of universal primers for amplification of polymorphic non-coding regions of mitochondrial and chloroplast DNA in plants. Molecular Ecology, 4: 129-131. 


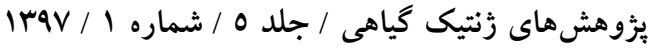

Dumolin-Lapegue, S., Pemonge, M.H. and Petit, R.J. (1997). An enlarged set of consensus primers for the study of organelle DNA in plants. Molecular Ecology, 6: 393-397.

Fujii, N., Tomaru, N., Okuyama, K., Koike, T., Mikami, T., and Ueda, K. (2002). Chloroplast DNA phylogeography of Faguscreneta (Fagaceae) in Japan. Plant Systematics Evolution, 232(1-2): 21-33.

Gielly, L. and Taberlet, P. (1994). The use of chloroplast DNA to resolve plant phylogenies. Noncoding vs. Rbcl sequences. Molecular Biology and Evolution, 11: 769-777.

Grivet, D., Heinze, B., Vendraminà, G.G. and Petit, R.J. (2001). Genome walking with consensus primers: Application to the large single copy region of chloroplast DNA. Molecular Ecology Notes, 1: 345-349.

Heuertz, M., Fineschi, S., Anzidei, M., Pastorelli, R., Salvini, D., Paule, L., Frascaria-Lacoste, N., Hardy, O.J., Vekemans, X. and Vendramin, G.G. (2004). Chloroplast DNA variation and postglacial recolonization of common ash (Fraxinus excelsior L.) in Europe. Molecular Ecology, 13: 3437-3452.

Ishikawa, S., Kato, S., Imakawa, S., Mikami, T. and Shimamoto, Y. (1992). Organel DNA polymorphism in apple cultivars and rootstocks. Theoretical and Applied Genetics, 83: 963-967.

Jahangirzadeh Khiavi, Sh., Zamani, Z., Mardi, M. and Fatahi Moghdam, M. (2013). Evaluation of Chloroplast relationship between some apple genotype from Azerbaijan of Iran and their comparison with other local genotypes, cultivars and rootstocks. African Journal of Agricultural Research, 8(1): 106-112.

Katayama, H. and Uematsu, C. (2005). Structural analysis of chloroplast DNA in Prunus (Rosaceae): Evolution, genetic diversity and unequal mutations. Theoretical and Applied Genetics, 111:1430-1439.

Kato, S., Ishikawa, S., Imakawa, S., Komori, S., Mikami, T. and Shimamoto, Y. (1993). Mitochondrial DNA restriction fragment length polymorphisms in Malus species. Plant Breeding, 111: $162-165$.

Kucuk, O., Gulbitti-Onarici, S. and Sumer, S. (2006). RFLP of analyses of an intergenic spacer region of chloroplast DNA in some wild wheat species. African Journal of Biotechnology, 5(22): 2058-2061.

Manie, A. (2001). Apple and its Culture. Technical Publications Companies in Iran. Tehran, IR (In Persian).

Matsumoto, S., Wakita, H. and Soejima, J. (1997). Chloroplast DNA probes as an aid in the molecular classification of Malus species. Scientia Horticulturae, 70: 81-86.

Mohanty, A., Martín, J.P. and Aguinagalde, I. (2001). Chloroplast DNA study in wild populations and some cultivars of Prunusavium L. Theoretical and Applied Genetics, 103: 112-117.

Palmer, J.D. (1987). Chloroplast DNA evolution and biosystematic uses of chloroplast DNA variation. American Society of Naturalists, 130: S6-S29.

Panda, S., Pedro Martin, J. and Aguinaglde, I. (2003). Chloroplast DNA study in sweet cherry cultivars (Prunusavium L.) using PCR-RFLP method. Genetic Resources and Crop Evolution, 50: 489-495.

Salehi Shanjani, P. (2004). Chloroplast DNA phylogeography of Fagus orrientalisLipsky in Iran. Journal of Iran Biology, 17(2): 117-126 (In Persian).

Taberlet, P., Gielly, L., Pautou, G. and Bouvet, J. (1991). Universal primers for amplification of three non-coding regions of chloroplast DNA. Plant Molecular Biology, 17: 1105-1109.

Turkec, A., Sayar, M. and Heinze, B. (2006). Identification of sweet cherry cultivars (Prunusavium L.) and analysis of their genetic relationships by chloroplast sequence-characterised amplified regions (cpSCAR). Genetic Resources and Crop Evolution, 53: 1635-1641.

Widmer, A. and Baltisberger, M. (1999). Extensive intraspecific chloroplast DNA (cpDNA) variation in the alpine Drabaaizoides L. (Brassicaceae): Haplotype relationships and population structure. Molecular Ecology, 8: 1405-1415.

Zeinalabedini, M., Mahjourhat, K., Khayam-Nekoui, M., Grigorian, V., Toorchi, M., Dicenta, F. and Martinez-Gomez, P. (2007). Molecular characterization of almond cultivars and related wild species using nuclear and chloroplast DNA markers. Journal of Food, Agriculture \& Environment, 5(3\&4): 242-247. 


\title{
Comparison of Chloroplast DNA Diversity in Some Iranian Apple Genotypes, Commercial Cultivars and Rootstocks
}

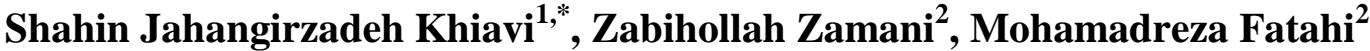 and Masoumeh Ashourpour ${ }^{3}$}

1- Assistant Professor, Tea Research Center, Horticultural Sciences Research Institute, Agricultural Research, Education and Extension Organization (AREEO), Lahijan, Iran

2- Professor, Department of Horticulture science, Faculty of Agriculture, University of Tehran, Karaj, Iran

3- Associate Professor, Department of Horticulture science, Faculty of Agriculture, University of Tehran, Karaj, Iran

4- M.S of Organization of Agriculture - Guilan branch, Rasht, Iran

(Received: July 5, 2017 - Accepted: March 11, 2018)

\begin{abstract}
The chloroplastic DNA of 64 accessions of apple (Malus spp.) (54 Iranian genotypes, five commercial cultivars and five rootstocks) were analyzed to reveal their haplotypes by using Polymerase Chain Reaction-Restriction Fragment Length Polymorphism (PCR-RFLP) method. Approximately 4320 bp of the chloroplast genome was analyzed, by using two chloroplast universal primer pairs and two restriction enzymes (EcoRI and $M s e \mathrm{I})$. All the mutations detected were insertion-deletions been in the range between 10-40 bp. The combination of all the mutations resulted to six haplotypes $(\mathrm{H} 1, \mathrm{H} 2, \mathrm{H} 3$, H4, H5 and H6) in the studied apple accessions. It was defined that the Iranian apple rootstock 'GamiAlmasi' had a specific haplotype form all the other studied accessions. It was approved that cpDNA diversity data can be considered for phylogenetic studies in this plant and the polymorphism determined in cytoplasmic genome by PCR-RFLP method can help to understand the maternal inheritance in apple.
\end{abstract}

Keywords: Chloroplast universal primer, Restriction enzyme, Malus Spp, Haplotype, PCR-RFLP

\footnotetext{
* Corresponding Author, E-mail: sh.jahangirzadeh@ areeo.ac.ir
} 